\title{
Heart failure supported by veno-arterial extracorporeal membrane oxygenation (ECMO): a systematic review of pre-clinical models
}

Silver Heinsar ${ }^{1,2+}$, Sacha Rozencwajg ${ }^{1,3^{*}+}$ D, Jacky Suen ${ }^{1 *}$, Gianluigi Li Bassi ${ }^{1}$, Maximilian Malfertheiner ${ }^{1,4}$, Leen Vercaemst ${ }^{5}$, Lars Mikael Broman ${ }^{6,7}$, Matthieu Schmidt ${ }^{2}$, Alain Combes ${ }^{2}$, Indrek Rätsep ${ }^{3}$, John F. Fraser ${ }^{1}$, Jonathan E. Millar ${ }^{1,8}$ and on behalf of the European Extracorporeal Life Support Organisation (EuroELSO) Innovations Workgroup \& the National Health Medical Research Council Australia Centre of Research Excellence for Advanced Cardio-respiratory Therapies Improving Organ Support (NHMRC CREACTIONS)

* Correspondence: sacha. rozencwajg@aphp.fr; j.suen1@uq. edu.au

†Sacha Rozencwajg and Silver Heinsar contributed equally to this work.

${ }^{1}$ Critical Care Research Group, The Prince Charles Hospital, University of Queensland, Chermside, Brisbane, Australia

Full list of author information is available at the end of the article

\begin{abstract}
Objectives: Veno-arterial extracorporeal membrane oxygenation (VA-ECMO) is increasingly being used to treat patients with refractory severe heart failure. Large animal models are developed to help understand physiology and build translational research projects. In order to better understand those experimental models, we conducted a systematic literature review of animal models combining heart failure and $\mathrm{VA}-\mathrm{ECMO}$.
\end{abstract}

Studies selection: A systematic review was performed using Medline via PubMed, EMBASE, and Web of Science, from January 1996 to January 2019. Animal models combining experimental acute heart failure and ECMO were included. Clinical studies, abstracts, and studies not employing VA-ECMO were excluded.

Data extraction: Following variables were extracted, relating to four key features: (1) study design, (2) animals and their peri-experimental care, (3) heart failure models and characteristics, and (4) ECMO characteristics and management.

Results: Nineteen models of heart failure and VA-ECMO were included in this review. All were performed in large animals, the majority $(n=13)$ in pigs. Acute myocardial infarction $(n=11)$ with left anterior descending coronary ligation $(n=9)$ was the commonest mean of inducing heart failure. Most models employed peripheral VA-ECMO ( $n=14)$ with limited reporting.

Conclusion: Among models that combined severe heart failure and VA-ECMO, there is a large heterogeneity in both design and reporting, as well as methods employed for heart failure. There is a need for standardization of reporting and minimum dataset to ensure translational research achieve high-quality standards.

Keywords: Heart failure, Extracorporeal membrane oxygenation, Animal models 


\section{Introduction}

Veno-arterial extracorporeal membrane oxygenation (VA-ECMO) is a therapeutic option for critically ill patients with cardiogenic shock, pulmonary embolism, or septic shock who are refractory to conventional treatments [1-3]. It consists of an extracorporeal life support (ECLS) circuit and a membrane lung with a venous drainage and an arterial return. Advances in technology, miniature ECMO consoles and improved circuit biocompatibility have exponentially increased the use of VA-ECMO over the last decade and helped broaden its indications $[4,5]$. To further improve outcomes and reduce complications associated with the use of VA-ECMO, high-quality clinical research is required [6].

Animal models constitute a cornerstone of critical care research, especially in the field of mechanical organ support, as they can provide a basis for understanding physiology and design relevant clinical trials. Although the ultimate goal of animal studies is to reflect the clinical scenario, the variability in methods used sometimes makes it difficult to directly translate the results obtained into clinically valuable therapeutic approaches. Multiple animal models using VA-ECMO have been published over many years; however, a comprehensive comparison between different models, in terms of feasibility and methods, is lacking, causing controversy within the field.

Therefore, we conducted a systematic review to summarize distinctive features of available animal models of heart failure supported by VA-ECMO, and to highlight potential limitations, with the goal of identifying best practices for use in the design of future studies.

\section{Methods}

This systematic review was performed following PRISMA guidelines [7]. The design was prepared in accordance with the SYRCLE guidelines [8], and the protocol was published on the PROSPERO website (https://www2.le.ac.uk/library/find/databases/p/prospero) under the registration number CRD42018090364.

\section{Inclusion and exclusion criteria}

Our review covered animal models of heart failure supported by VA-ECMO with no restriction to the publication language. This comprised studies of all types which matched the following PICO approach: (1) population defined as animals with heart failure; (2) intervention defined as animals treated with VA-ECMO; (3) controls defined as animals not treated with VA-ECMO (when the study involved more than one group); and (4) outcomes comprised data reporting quality, characteristics of heart failure, and ECMO support.

Studies using VA-ECMO in the context of cardiac arrest were excluded, as extracorporeal cardiopulmonary resuscitation (ECPR) represents a different clinical scenario and carries its own definition [9].

\section{Search strategy and data extraction}

We used PubMed, Web of Science, and EMBASE to search for animal models of heart failure on VA-ECMO from January 1st, 1996 to January 1st, 2019. The search contained keywords relevant to cardiac failure and VA extracorporeal membrane 
oxygenation, applying pre-published animal filters when relevant [10, 11]. References from identified studies and relevant review articles were also searched for additional eligible citations. The full search strategy is provided in the Supplementary materials.

Two independent reviewers ( $\mathrm{SH}$ and IR) initially screened articles based on their titles and abstracts. Full-text articles were subsequently independently reviewed (SH and SR) and data were extracted according to a data extraction form available in the Supplementary materials eTable 1 . In case of discrepancies, an independent reviewer was consulted (JM). We only included data that were presented in the reviewed paper itself, except when the paper relied on a model described elsewhere by the same authors.

\section{Study outcomes}

\section{Quality of reporting}

Global quality of data reporting was assessed using the ARRIVE guidelines which provide specific recommendations for methodology and results in animal studies (see Supplementary materials eTables 2 and 3) [12].

To assess the methodology used for acute heart failure models, we compared criteria used by each study with established guidelines or large international trials, adapted to fit with animal practice [13-17]. Although not every study was designed to study cardiogenic shock, specifically, we considered it of matter as it is the clinical situation in which VA-ECMO is mostly used. We thus considered that a study had defined cardiogenic shock adequately if (1) it was consistent with the guidelines in force at the time of the experiment; (2) it used a combination of two criteria present in any guidelines including at least one clinical criterion; or (3) it used one criterion present in any guidelines and successfully induced acute heart failure. When a study failed to meet cardiogenic shock criteria, it was considered as "acute heart failure without cardiogenic shock."

\section{Heart failure models: characteristics and comparison}

The data extraction protocol consisted of the following parameters: type of heart failure induction, methods used to induce heart failure, and criteria used to define cardiogenic shock (as described above) and complications. Details of the definitions used can be found in the Supplementary materials eTable 1.

\section{VA-ECMO support characteristics}

Parameters included in the data extraction protocol consisted of the type of console/ pump, oxygenator, priming solution, ECMO configuration and access, cannulation technique and size, anticoagulation drug and target. Details of the definitions used can be found in the Supplementary materials eTable 1.

\section{Statistical analysis}

Data were analyzed using descriptive statistics and reported as number of occurrences (percentage) or mean \pm standard deviation, unless otherwise stated. Given the heterogeneous nature of included studies and taking into account that the aim of the review is to characterize and assess the quality of the models rather than the study outcomes, no attempt was made at meta-analysis. 


\section{Results}

\section{Study selection and animal characteristics}

A total of 349 articles were retrieved through the search from PubMed, Web of Science, and EMBASE. After removing duplicates, 270 studies were screened by titles and abstracts of which 21 full-text articles were reviewed to finally include 19 studies in the systematic review [18-36] (Fig. 1).

The median study population was ten animals per study (from two to 26) and the majority $(12 / 19,63 \%)$ used porcine models $[18,19]$. Animal age was missing in nearly half of the studies reviewed, while anesthetic and airway management were only reported in $22 \%$ and $17 \%$ of studies, respectively (details can be found in the Supplementary materials eTable 4). Housing and husbandry were systematically omitted, and in 12 out of 19 studies, animals' fasting protocol was not mentioned. Ten studies (53\%) had several groups and could thus be qualified as interventional studies (Table 1).

\section{Quality of reporting}

Detailed results regarding the concordance of the applied methodology with the ARRIVE checklist can be found in the Supplementary materials eTables 2 and 3.

General quality of reporting was considered mediocre due to the marginal description of materials and methods and to the heterogeneity in the interventions. As for the description of the methods used to develop heart failure, four studies did not report any criteria to define heart failure [20-23]. One study did not present hemodynamic results, rendering it impossible to assess if the cardiogenic shock was achieved during the experiment, or not [24]. Of the remaining 15 studies, ten (66\%) used criteria consistent with adequate cardiogenic shock definition and seven (47\%) reported enough data to confirm that animals reached cardiogenic shock (the two Esmolol-induced models and

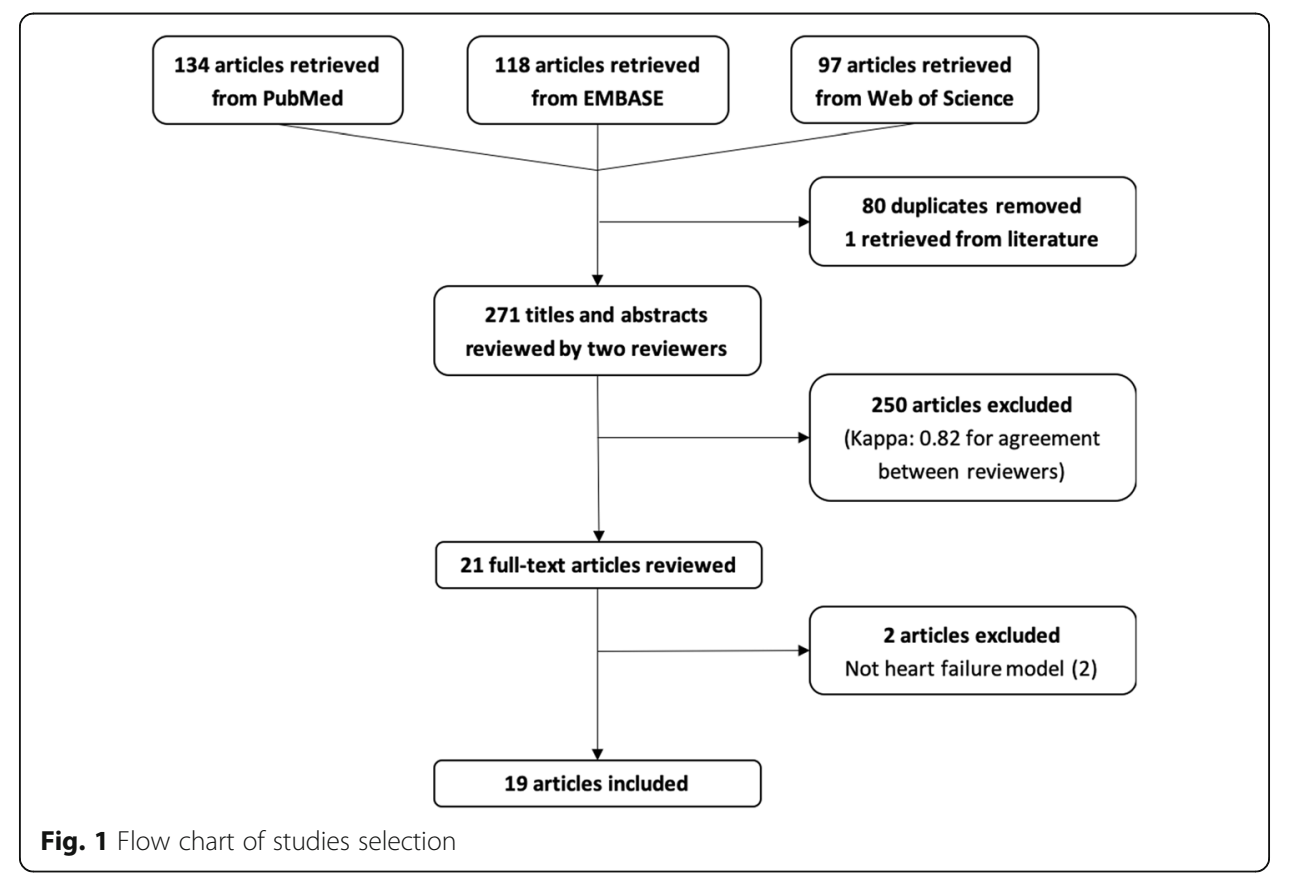


Table 1 Type of studies and main animal characteristics (sorted by animal type)

\begin{tabular}{|c|c|c|c|c|c|c|c|c|}
\hline Study & Year & Species & Study type & $\begin{array}{l}\text { Animal } \\
\text { age }^{a}\end{array}$ & Number & $\begin{array}{l}\text { Heart failure } \\
\text { model }\end{array}$ & $\begin{array}{l}\text { ECMO } \\
\text { configuration }\end{array}$ & Group(s) \\
\hline $\begin{array}{l}\text { Sakamoto } \\
\text { et al. }\end{array}$ & 2015 & Dogs & Other & Adult & 21 & $\begin{array}{l}\text { Myocardial } \\
\text { infarction }\end{array}$ & $V_{j-A f}$ & $\begin{array}{l}\text { ECMO with AMI }(n=13) \\
\text { ECMO without cardiac } \\
\text { failure }(n=8)\end{array}$ \\
\hline $\begin{array}{l}\text { Kawashima } \\
\text { et al. }\end{array}$ & 2011 & Dogs & Physiological & Adult & 6 & $\begin{array}{l}\text { Myocardial } \\
\text { infarction }\end{array}$ & RA-Af & - \\
\hline Yu et al. & 2008 & Dogs & Interventional & ND & 13 & $\begin{array}{l}\text { Myocardial } \\
\text { infarction }\end{array}$ & RA-Af & $\begin{array}{l}\text { Pulsatile ECMO }(n=7) \\
\text { Non-pulsatile ECMO } \\
(n=6)\end{array}$ \\
\hline $\begin{array}{l}\text { Segesser } \\
\text { et al. }\end{array}$ & 2008 & $O x$ & Physiological & ND & 5 & Pacing & $\begin{array}{l}V f \text { and } P^{b}- \\
A_{C A R}\end{array}$ & - \\
\hline $\begin{array}{l}\text { Møller- } \\
\text { Helgestad } \\
\text { et al. }\end{array}$ & 2018 & Pigs & Interventional & ND & 14 & $\begin{array}{l}\text { Myocardial } \\
\text { infarction }\end{array}$ & Vf-Af & $\begin{array}{l}\text { ECMO }(n=6) \\
\text { Impella }(n=6)\end{array}$ \\
\hline Ostadal et al. & 2018 & Pigs & Physiological & $\begin{array}{l}4-5 \\
\text { months }\end{array}$ & 16 & $\begin{array}{l}\text { Myocardial } \\
\text { hypoxia }\end{array}$ & Vf-Af & - \\
\hline $\begin{array}{l}\text { Simonsen } \\
\text { et al. }\end{array}$ & 2018 & Pigs & Interventional & 90 days & 12 & $\begin{array}{l}\text { Carbon } \\
\text { monoxide } \\
\text { poisoning }\end{array}$ & Vf-Af & $\begin{array}{l}\text { ECMO }(n=6) \\
\text { Conventional } \\
\text { treatment }(n=6)\end{array}$ \\
\hline Janak et al. & 2017 & Pigs & Physiological & $\begin{array}{l}\text { 4-5 } \\
\text { months }\end{array}$ & 8 & $\begin{array}{l}\text { Myocardial } \\
\text { infarction }\end{array}$ & Vf-Af & - \\
\hline $\begin{array}{l}\text { Vanhuyse } \\
\text { et al. }\end{array}$ & 2017 & Pigs & Interventional & ND & 12 & $\begin{array}{l}\text { Myocardial } \\
\text { infarction }\end{array}$ & Vf-Af & $\begin{array}{l}\text { ECMO + normothermia } \\
(n=6) \\
\text { ECMO + hypothermia } \\
(n=6)\end{array}$ \\
\hline Esposito et al. & 2016 & Pigs & Interventional & Adult & 10 & $\begin{array}{l}\text { Myocardial } \\
\text { infarction }\end{array}$ & Vf-Af & $\begin{array}{l}\mathrm{ECMO}(n=4) \\
\text { TandemHeart }(n=4)\end{array}$ \\
\hline Hala et al. & 2016 & Pigs & Physiological & $\begin{array}{l}\text { Up to } 6 \\
\text { months }\end{array}$ & 5 & Pacing & Vf-Af & - \\
\hline Itoh et al. & 2015 & Pigs & Interventional & ND & 14 & Pacing & RA-AO & $\begin{array}{l}\text { Pulsatile ECMO }(n=7) \\
\text { Non-pulsatile ECMO } \\
(n=7)\end{array}$ \\
\hline Ostadal et al. & 2015 & Pigs & Physiological & $\begin{array}{l}4-5 \\
\text { months }\end{array}$ & 5 & $\begin{array}{l}\text { Myocardial } \\
\text { hypoxia }\end{array}$ & Vf-Af & - \\
\hline Brehm et al. & 2014 & Pigs & Physiological & ND & 7 & $\begin{array}{l}\text { Drug-induced } \\
\text { (Esmolol) }\end{array}$ & Vf-Af & - \\
\hline $\begin{array}{l}\text { Kajimoto } \\
\text { et al. }\end{array}$ & 2014 & Pigs & Interventional & 30-57 days & 19 & $\begin{array}{l}\text { Myocardial } \\
\text { infarction }\end{array}$ & RA-AO & $\begin{array}{l}\text { ECMO with AMI }(n=6) \\
\text { ECMO with AMI and T3 } \\
\text { supplementation }(n=6) \\
\text { ECMO without cardiac } \\
\text { failure }(n=5)\end{array}$ \\
\hline Zhu et al. & 2014 & Pigs & Interventional & $\begin{array}{l}4-5 \\
\text { months }\end{array}$ & 24 & $\begin{array}{l}\text { Myocardial } \\
\text { infarction }\end{array}$ & Vf-Af & $\begin{array}{l}\text { ECMO }(n=8) \\
\text { Control/sham }(n=8) \\
\text { Drug therapy }(n=8)\end{array}$ \\
\hline Bartoli et al. & 2013 & Pigs & Interventional & ND & 47 & $\begin{array}{l}\text { Myocardial } \\
\text { infarction }\end{array}$ & $V j-A_{A O}{ }^{c}$ & $\begin{array}{l}\text { ECMO vs IABP }(n=10) \\
\text { ECMO vs PFVAD }(n= \\
10) \\
\text { ECMO vs CFVAD }(n=6)\end{array}$ \\
\hline Sauren et al. & 2007 & Sheep & Physiological & ND & 7 & $\begin{array}{l}\text { Myocardial } \\
\text { infarction }\end{array}$ & $\begin{array}{l}\text { Vf-Af and } \\
V f-A O\end{array}$ & - \\
\hline Naito et al. & 2017 & Sheep & Physiological & Adult & 6 & $\begin{array}{l}\text { Drug-induced } \\
\text { (esmolol) }\end{array}$ & $V j-A_{A O}{ }^{c}$ & - \\
\hline
\end{tabular}

$A M I$ acute myocardial infarction; $A f$ femoral artery; $A O$ aorta; $A R$ right atrium; asc. ascending; CAR carotid artery; $C F V A D$ continuous-flow ventricular assist device; $P$ pulmonary artery; $P F V A D$ pulsatile-flow ventricular assist device; $V f$ femoral vein; $V j$ jugular vein

${ }^{a}$ Animal age is written as per original paper statement

${ }^{b}$ Venous canula was first inserted into the right atrium through femoral access (as per peripheral VA-ECMO) and then pushed onto the left pulmonary artery; arterial canula was maintained in the carotid throughout the experiment (as per pediatric ECMO configuration)

'Arterial canula was inserted surgically directly into the abdominal aorta through a graft 
five models of acute myocardial infarction). The last five studies were considered to have reach acute heart failure but without cardiogenic shock (Table 2).

\section{Heart failure models}

\section{Characteristics of heart failure models}

Heart failure models are presented in Fig. 2 and their characteristics are summarized in Table 3. All models but one [25] described acute heart failure. The majority of studies used an acute myocardial infarction (AMI) model $(n=11)$ with left anterior descending (LAD) coronary occlusion, mostly done through ligation. Other models used pacing ( $n=$ 3) $[22,25,26]$ to induce ventricular fibrillation (VF), esmolol infusion $(n=2)[27,28]$, myocardial hypoxia $(n=2)[29,30]$, or carbon monoxide poisoning $(n=1)$ [31]. The AMI model was systematically complicated with at least two episodes of irreversible VF leading to death, ranging from 9 to $50 \%$ of the subjects. This model seemed to display more complications than the others (no statistical analysis could be made because of poor reporting).

\section{VA-ECMO support characteristics}

Characteristics of VA-ECMO are summarized in Table 4. Most studies (17/19) employed peripheral or combined cannulation through percutaneous $(n=6)$ or a surgical cut-down $(n=4)$. However, in nine out of 19 studies, cannulation methods were not described. Cannula size was omitted in four studies and none reported the cannula length. Furthermore, and importantly, arterial tip positioning was only confirmed in three $[25,29,30]$ out of the twelve studies which used peripheral return cannulation. All studies used intravenous infusion of heparin, yet seven of the 19 studies (37\%) did not report any anticoagulation strategy targets. The combination of ECMO consoles, pumps, and oxygenators across studies was highly diverse. Finally, the priming solution was described only in six studies with wide variation [18, 21, 22, 24, 25, 32].

\section{Discussion}

In this systematic review, we provided a comprehensive overview of available preclinical models of heart failure supported by VA-ECMO. The main findings of pooled data can be summarized as follows: (1) there was a large heterogeneity in the development of heart failure-AMI model with LAD occlusion was preferentially used and experiments were mostly performed on pigs, (2) materials and methods were poorly reported.

\section{Main findings}

\section{Deficiencies in reporting and risks associated}

Pre-clinical studies in large animals require consistent and reproducible methods in order to ensure comparability across studies, and ultimately translation into clinical studies. Concerns have been raised regarding the reporting of animal experiments as numerous studies displayed insufficient reporting of methods [37, 38], and our results are in line with those concerns. For example, animals' characteristics and conditions (e.g., age, feeding management, anesthetic management) may impact animal health or lead to variability in treatment responses [38,39]. Even more concerning, four studies 
Table 2 Criteria used to define cardiogenic shock adapted to animal practice

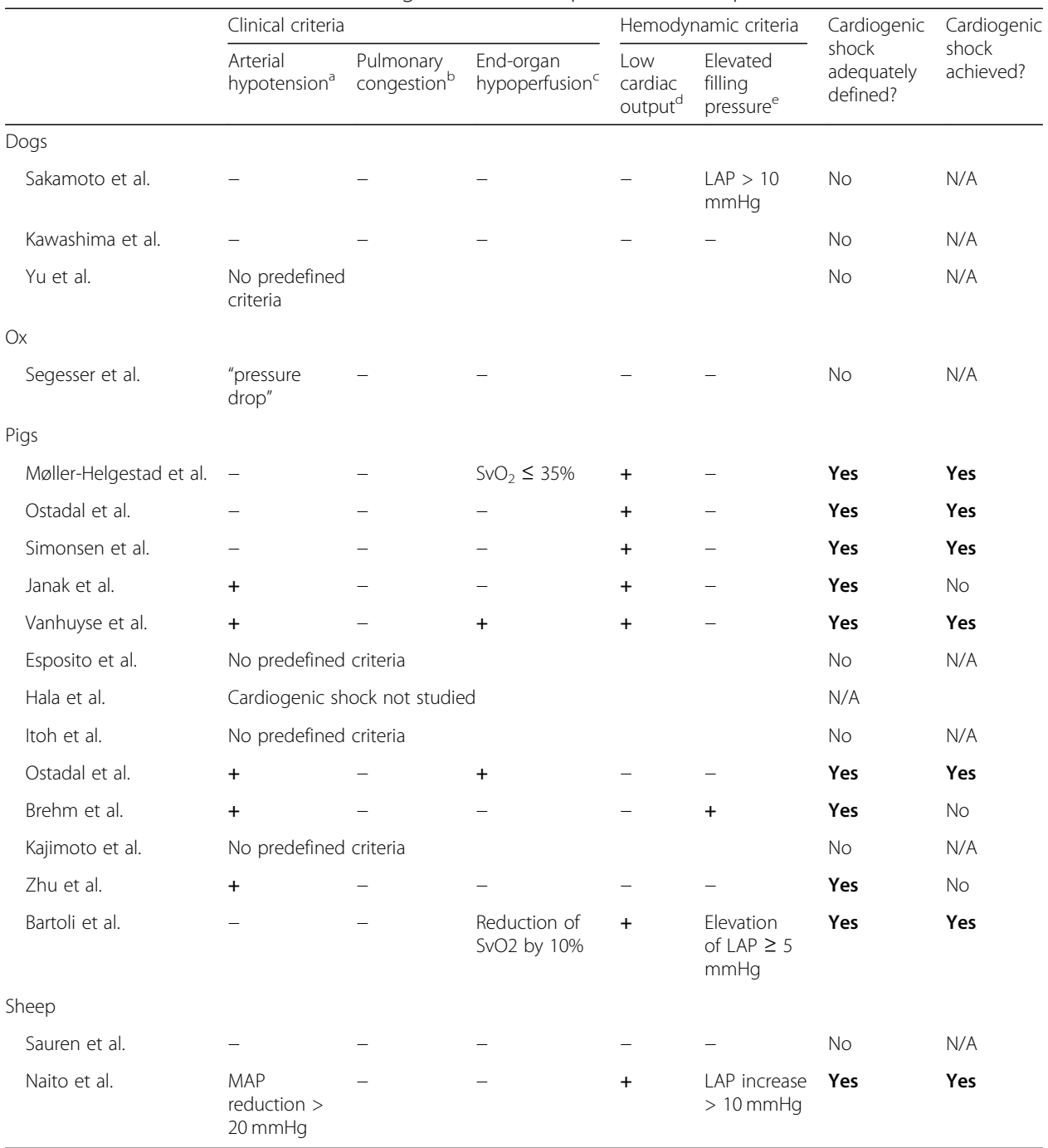

Data were divided into clinical and hemodynamic variables with "+" indicating the criterion was met and "-" indicating the criterion was not met. When a criterion was correctly defined but met a different threshold, we considered the criterion to be met and wrote the precise threshold used in the study. We considered that a study had defined cardiogenic shock adequately if (i) it was consistent with the guidelines in force at the time of the experiment; (ii) it used a combination of two criteria present in any guidelines including at least one clinical criterion; or (iii) it used one criterion in the context of acute heart failure induction. We considered that a study had achieved cardiogenic shock if those criteria were met during the experiment. Otherwise, it was considered as "acute heart failure without cardiogenic shock". $\angle A P$ left atrial pressure; MAP mean arterial pressure; SvO2 venous saturation of oxygen

${ }^{a}$ Systolic blood pressure $<90 \mathrm{mmHg}$ or inotrope, mean arterial pressure (MAP) $<65 \mathrm{mmHg}$, or $>20 \%$ drop in MAP. Based on criteria from SHOCK and IABP-SHOCK II Trial and NICE Clinical Guidelines

${ }^{\mathrm{b}}$ Criteria from IABP-SHOCK II trial

'Altered mental status, cold/clammy skin and extremities, urine output $<0.5 \mathrm{~mL} / \mathrm{kg} / \mathrm{h}, \mathrm{pH}<7.35$, elevated serum creatinine, lactate $>2.0 \mathrm{mmol} / \mathrm{L}$. $\mathrm{SvO}_{2}$ threshold based on criteria from SHOCK and IABP-SHOCK II Trial, NICE, and ESC Clinical Guidelines

${ }^{d}$ Cardiac index $(\mathrm{Cl}) \leq 2.2 \mathrm{~L} / \mathrm{min} / \mathrm{m}^{2}$ or cardiac output $(\mathrm{CO})<3.5 \mathrm{~L} / \mathrm{min}$ or $>20 \%$ drop in CO. Based on criteria from SHOCK and IABP-SHOCK II Trials and ESC Clinical Guidelines

ePulmonary capillary wedge pressure (PCWP) $\geq 15 \mathrm{mmHg}$ or increased left atrial pressure (LAP). Based on criteria from SHOCK Trial and ESC Clinical Guidelines

failed to report the definition of heart failure used in their experiment. It was also found that serious adverse effects, e.g., premature animal death, were poorly described. It should be taken into account that a limited description of adverse effects poses a serious threat to the validity of experimental studies and constitutes substantial bias in post hoc systematic reviews and meta-analyses [40]. 


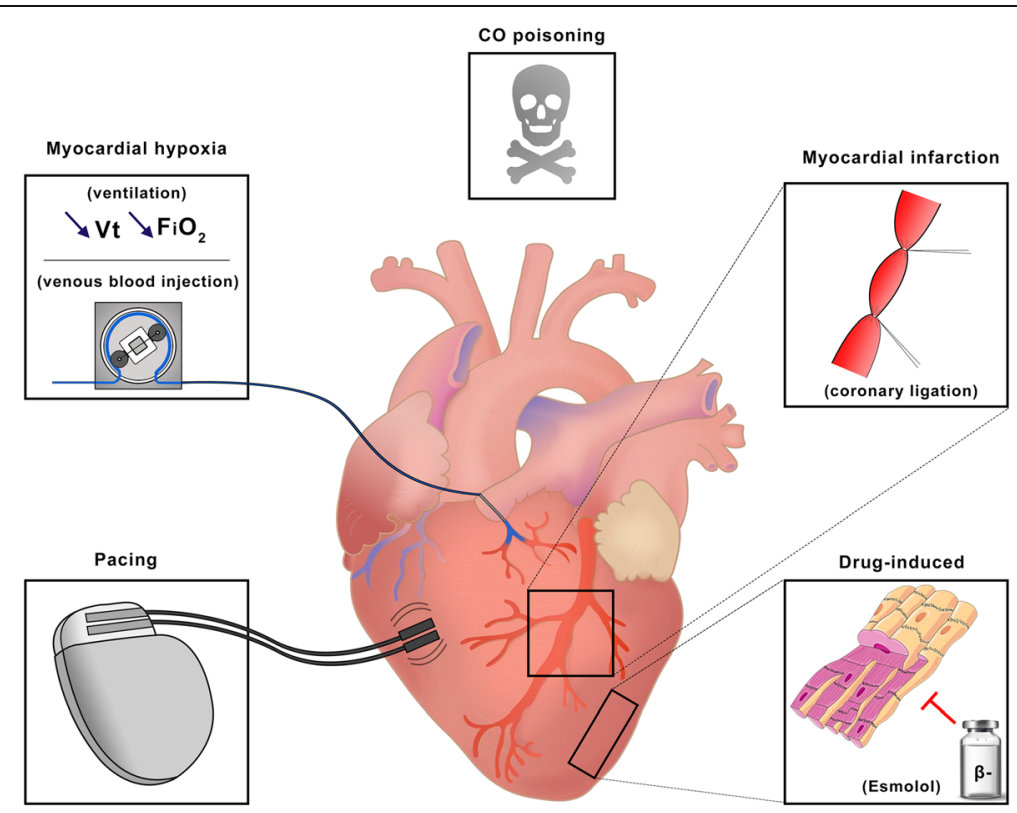

Fig. 2 Representation of the five heart failure models that were used in our review. From left to right: ventricular pacing, myocardial hypoxia (through lowering of mechanical ventilation or perfusion of desaturated blood in the coronary arteries), CO poisoning, myocardial infarction, and drug-induced heart failure. CO, carbon monoxide; FiO2, inspired fraction of oxygen; Vt, tidal volume. Images were obtained from https://smart.servier.com and are available under a creative commons license

\section{Heterogeneity in heart failure models}

With regard to the development of heart failure, it should be mentioned that the most common indication of VA-ECMO is cardiogenic shock refractory to medical therapy [41]. Thus, to translate animal data to clinical practice, the induced heart failure had to be severe. In our analysis, we used rather broad criteria to define cardiogenic shock, i.e., features described in three different guidelines and a reduction in mean arterial pressure and cardiac output. Irrespective of our wide-ranging criteria, seven out of the 18 studies investigating acute heart failure failed to meet those diagnostic criteria and were considered as "acute heart failure without cardiogenic shock." Regarding the models used, one should be careful when using the term "acute myocardial infarction" as the methods used behind this term were shown to be variable-from sequential ligation of left circumflex side branches to total proximal irreversible LAD ligation which may impact the severity and predominance of ventricular dysfunction.

\section{Heterogeneity in ECMO support}

There is a growing consensus that a more accurate terminology is needed in the field of ECLS. As such, it has recently been asserted that "VA-ECMO" should not be applied as an umbrella term for various situations but should be used only to denote the circulatory element of extracorporeal organ support (ECOS) [42]. In the same way, the Extracorporeal Life Support Organization (ELSO, Ann Arbor, MI, USA) has recently published an international multidisciplinary standardized nomenclature for definitions and terminology for ECLS [9]. 
Table 3 Detailed characteristics of heart failure model

\begin{tabular}{|c|c|c|c|c|}
\hline Study & $\begin{array}{l}\text { Heart } \\
\text { failure }\end{array}$ & Injury model & Procedure description & Complications \\
\hline \multicolumn{5}{|l|}{ Dogs } \\
\hline Sakamoto et al. & Acute & $\begin{array}{l}\text { Myocardial } \\
\text { infarction }\end{array}$ & LAD ligation with suture & - \\
\hline Kawashima et al. & Acute & $\begin{array}{l}\text { Myocardial } \\
\text { infarction }\end{array}$ & $\begin{array}{l}\text { LAD ligation (sequential from } \\
\text { distal to proximal every } 10 \mathrm{~min} \text { ) }\end{array}$ & $\begin{array}{l}\text { Death from VF } \\
\text { ( } 3 \text { out of } 6)\end{array}$ \\
\hline Yu et al. & Acute & $\begin{array}{l}\text { Myocardial } \\
\text { infarction }\end{array}$ & LAD ligation (7 min) & - \\
\hline \multicolumn{5}{|l|}{ Ox } \\
\hline Segesser et al. & Acute & Pacing & External stimulation to induce VF & - \\
\hline \multicolumn{5}{|l|}{ Pigs } \\
\hline $\begin{array}{l}\text { Møller-Helgestad } \\
\text { et al. }\end{array}$ & Acute & $\begin{array}{l}\text { Myocardial } \\
\text { infarction }\end{array}$ & $\begin{array}{l}\text { LMCA injection with alcohol } \\
\text { microspheres }\end{array}$ & $\begin{array}{l}\text { Death from VF } \\
\text { (2 out of } 14)\end{array}$ \\
\hline Ostadal et al. & Acute & $\begin{array}{l}\text { Myocardial } \\
\text { hypoxia }\end{array}$ & $\begin{array}{l}\text { Switch mechanical ventilation } \\
\text { to } 5 \text { breaths/min, } 100 \mathrm{~mL} V_{T} \text {, } \\
\text { and FiO2 } 21 \%\end{array}$ & - \\
\hline Simonsen et al. & Acute & $\begin{array}{l}\text { Carbon } \\
\text { monoxide } \\
\text { poisoning }\end{array}$ & Carbon monoxide administration & $\begin{array}{l}\text { Cardiac arrest } \\
\text { ( } 6 \text { out of } 12) \text { leading } \\
\text { to death }(n=5)\end{array}$ \\
\hline Janak et al. & Acute & $\begin{array}{l}\text { Myocardial } \\
\text { infarction }\end{array}$ & $\begin{array}{l}\text { LAD and LCX occlusion by balloon } \\
\text { inflation ( } 5 \text { min, echo-guided) }\end{array}$ & - \\
\hline Vanhuyse et al. & Acute & $\begin{array}{l}\text { Myocardial } \\
\text { infarction }\end{array}$ & $\begin{array}{l}\text { LAD ligation (proximal) with } \\
\text { tourniquet ( } 60 \mathrm{~min} \text { ) }\end{array}$ & - \\
\hline Esposito et al. & Acute & $\begin{array}{l}\text { Myocardial } \\
\text { infarction }\end{array}$ & $\begin{array}{l}\text { LCX occlusion (proximal) by } \\
\text { balloon inflation ( } 30 \text { mins) }\end{array}$ & $\begin{array}{l}\text { Death from VF } \\
\text { (2 out of } 10)\end{array}$ \\
\hline Hala et al. & Chronic* & Pacing & Ventricular pacing (200 bpm) & - \\
\hline Itoh et al. & Acute & Pacing & $\begin{array}{l}\text { Direct } 3.5 \mathrm{~V} \text { alternate current to } \\
\text { induce VF }\end{array}$ & - \\
\hline Ostadal et al. & Acute & $\begin{array}{l}\text { Myocardial } \\
\text { hypoxia }\end{array}$ & $\begin{array}{l}\angle A D \text { or } L C x \text { perfusion with } \\
\text { venous blood }\end{array}$ & VF (2 out of 5$)$ \\
\hline Brehm et al. & Acute & $\begin{array}{l}\text { Drug-induced } \\
\text { (Esmolol) }\end{array}$ & $\begin{array}{l}\text { Esmolol bolus bolus at } 2 \mathrm{mg} / \mathrm{kg} \\
\text { into the LA }\end{array}$ & - \\
\hline Kajimoto et al. & Acute & $\begin{array}{l}\text { Myocardial } \\
\text { infarction }\end{array}$ & LAD ligation with sutures (10 min) & Death (2 out of 19) \\
\hline Zhu et al. & Acute & $\begin{array}{l}\text { Myocardial } \\
\text { infarction }\end{array}$ & $\begin{array}{l}\text { LAD ligation between diagonal } \\
\text { branches }\end{array}$ & Death (2 out of 24 ) \\
\hline Bartoli et al. & Acute & $\begin{array}{l}\text { Myocardial } \\
\text { infarction }\end{array}$ & LAD ligation (sequential) & $\begin{array}{l}\text { Death from } \\
\text { arrhythmias } \\
\text { (21 out of } 47 \text { ) }\end{array}$ \\
\hline \multicolumn{5}{|l|}{ Sheep } \\
\hline Sauren et al. & Acute & $\begin{array}{l}\text { Myocardial } \\
\text { infarction }\end{array}$ & LCx (or side branches) ligation & $\begin{array}{l}\text { "Unstable" } \\
\text { ( } 3 \text { out of } 7 \text { ) }\end{array}$ \\
\hline Naito et al. & Acute & $\begin{array}{l}\text { Drug-induced } \\
\text { (Esmolol) }\end{array}$ & $\begin{array}{l}\text { Esmolol bolus at } 2 \mathrm{mg} / \mathrm{kg} \text { into } \\
\text { the } \mathrm{LA} \text { and drip infusion (50 to } \\
500 \mathrm{mg} / \mathrm{kg} / \mathrm{min} \text { ) }\end{array}$ & - \\
\hline
\end{tabular}

bpm beats per minute; $L A D$ left anterior descending coronary; $L C X$ left circumflex coronary; $L M C A$ left main coronary artery; $V F$ ventricular fibrillation

*A delay of 4 to 8 weeks was respected in order to obtain clinical signs of heart failure

In our review, we highlighted the poor reporting of, and the lack of a unified terminology for, even very basic data: access (percutaneous versus surgical), priming solution, anticoagulation target, or cannula size. 


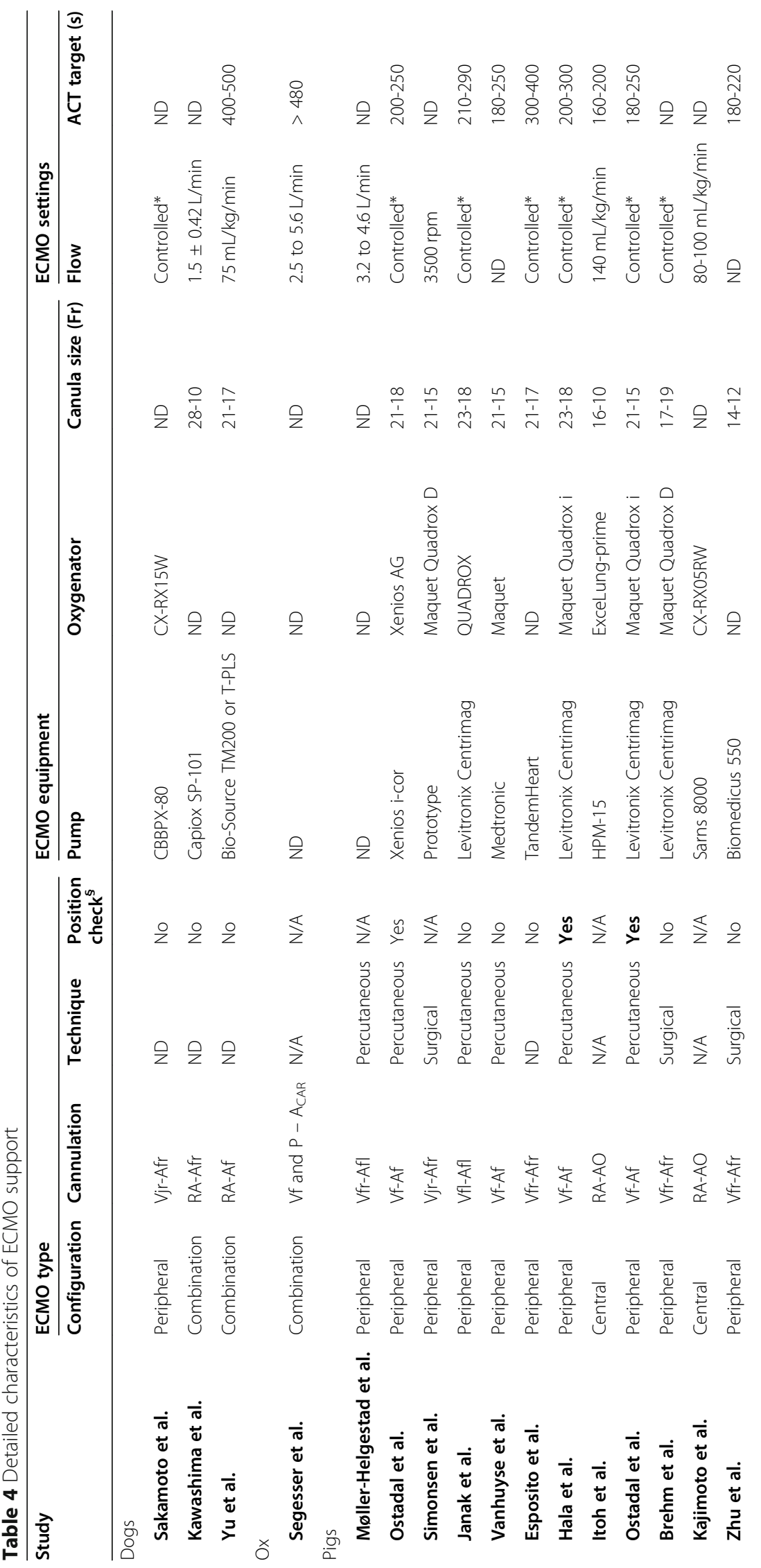




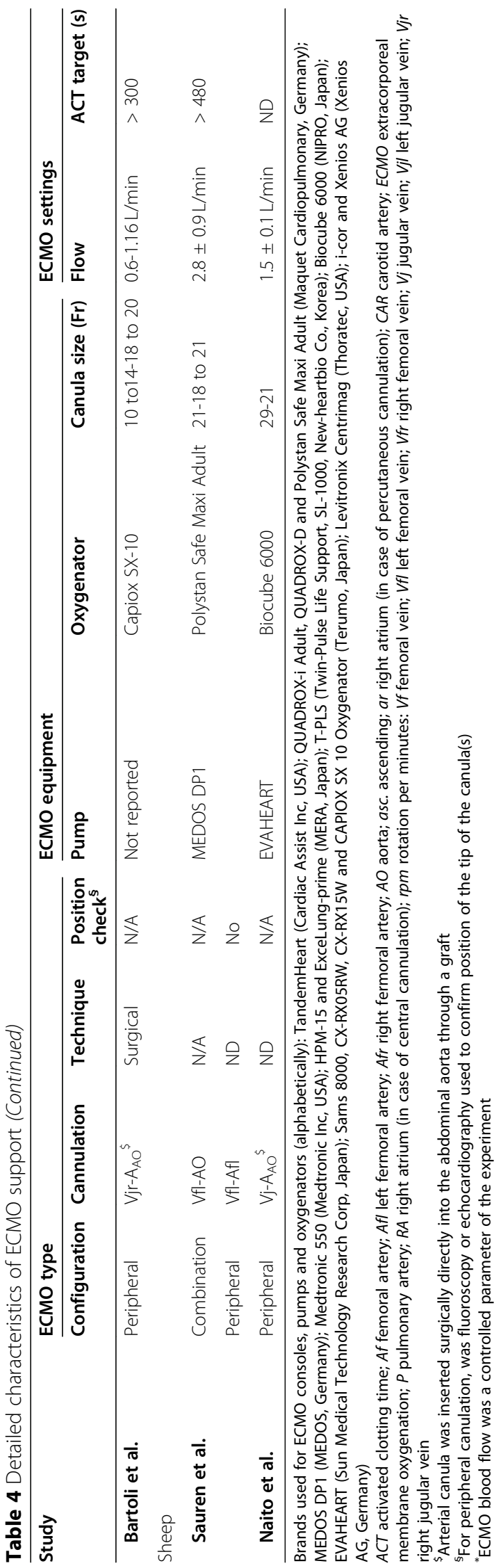




\section{Propositions for future studies}

\section{Choice of animal}

Small animals are usually chosen for their accessibility, a lower housing cost, shorter gestation times, and reduced costs for pharmacological treatment, as compared to larger animal models [43]. Even though we could not identify models combining heart failure and ECMO, rodent models supported by ECLS or ECMO have been developed [44-46]. These models should not be abandoned as they can bring preliminary mechanistic results, particularly at cellular or molecular levels, at a lower cost.

Nevertheless, in order to study the effects of VA-ECMO on cardiac failure (especially its physiological impact), considering the currently available technology and the severity of the condition, large animal models are the most adequate. The choice of specific animal species to be used should be based on local resources and laboratory experience. Nevertheless, some specificities are worth mentioning as they might help clinicians and scientists in their choice. In particular, when exploring upper-body blood flow, despite similar cerebral vascularization across different species, the left subclavian artery (LSCA) may be separated from the brachiocephalic trunk at its origin in pigs which may lead to (i) a different arterial curve between left and right upper-body leg, and (ii) a different brain vasoreactivity to laminar flow [47]. Vascular access is also to be mentioned, as sheep femoral arteries form an abrupt angle with the abdominal aorta, thus providing difficult percutaneous access. Finally, ovine and non-human primate models show greater similarity to humans in terms of thrombogenicity mechanisms as compared to dogs or pigs which may impact studies aiming at exploring in vivo impact of ECMO on coagulation $[48,49]$.

\section{Heart failure model and reporting}

Cardiogenic shock in humans is mostly caused by AMI or severe myocardial ischemia (anemia, hypoxia); therefore, the most frequently used animal models are developed through coronary artery occlusions [50]. Nevertheless, as found in our study, these models may produce severe and unpredictable adverse events, such as untreatable hemodynamic instability caused by ventricular arrhythmias. In the specific setting of VA-ECMO research, the extent of ischemic injury should be severe yet controllable in order to develop a sustainable cardiac failure, unless extensive and terminal heart failure is being investigated. Up to today, we have found that such models are limited to the use of esmolol [27, 28] and intra-myocardial injection of ethanol [51] - a recently described and promising method for which data still need to be reproduced. Other methods of inducing heart failure have been proposed, in particular, pressure overload models via cardiac banding-debanding (also known as thoracic aortic compressionTAC), leading to successful, precise, and reproducible results in small animals $[52,53]$. The aim of these models' is slightly different as they study the consequences of an "acute on chronic" heart failure. However, they are relevant for the subpopulation of patients which could undergo ECMO, and the characteristics of precision and reproducibility meet the criteria we identified to study the consequences of VA-ECMO. These models would therefore merit further evaluation, as studies on large animals are currently limited [54]. 


\section{VA-ECMO settings and reporting}

Unless required by the experiment protocol, we believe VA-ECMO settings and more generally hemodynamic support should be standardized to ensure comparability and translation into clinical studies. A clear definition of cardiogenic shock should be provided, and a strategy to support it (fluid therapy, inotropes, and vasopressors) as well as hemodynamic targets (MAP above $65 \mathrm{mmHg}$ with normalization of arteria lactate) as per current guidelines. Once VA-ECMO support has been started, cannulation and settings should be as standardized as possible as per latest guidelines or practice: femoral percutaneous access with arterial tip position confirmation, $60 \mathrm{~mL} / \mathrm{kg} / \mathrm{min}$ of ECMO blood flow, a membrane fraction of oxygen $\left(\mathrm{F}_{\mathrm{D}} \mathrm{O} 2\right)$ as low as possible in order to reach $\mathrm{SaO} 2$ of $92 \%$ on the right upper limb, with a sweep gas flow to maintain a stable arterial pH. Ventilation strategy under VA-ECMO is still highly debated, and we do not comment on this since it was not the scope of this review. In Table 5, we propose a minimum dataset based on the latest guidelines [55].

\section{Limitations}

Our study has several limitations. Firstly, data extraction into pre-defined categories may result in a simplification of the data presented in the studies reviewed. Secondly, we did not conduct a formal assessment of the risk of bias. Finally, we also excluded studies before 1996 from our analysis and thus, may have excluded viable models.

Table 5 Proposed minimum reporting dataset for pre-clinical models of heart failure supported by VA-ECMO

\begin{tabular}{|c|c|c|}
\hline Dataset & Example items & Notes/criteria proposed \\
\hline 1. Animal & $\begin{array}{l}\text { Species, age, sex, housing and } \\
\text { husbandry. }\end{array}$ & Use ARRIVE guidelines [12] \\
\hline $\begin{array}{l}\text { 2. Heart failure } \\
\text { model }\end{array}$ & $\begin{array}{l}\text { Method of injury including detailed } \\
\text { surgical/medical procedure, timing } \\
\text { and delay } \\
\text { Heart failure/cardiogenic shock } \\
\text { definition } \\
\text { Heart failure/cardiogenic shock } \\
\text { achievement }\end{array}$ & $\begin{array}{l}\text { Use latest guidelines and/or trials adapted to } \\
\text { fit with animal practice }\end{array}$ \\
\hline \multirow[t]{2}{*}{ 3. Hemodynamic } & Hemodynamic targets & $\begin{array}{l}\text { MAP > } 65 \mathrm{mmHg} \text {, arterial lactate }<2 \mathrm{mmol} / \mathrm{L} \\
\text { Items mandatory to report: LVOT VTI, LVEF, } \\
\text { aortic valve opening, pulse pressure }\end{array}$ \\
\hline & Hemodynamic support strategy & $\begin{array}{l}\text { Fluid support (type and volume per } \mathrm{kg} \text { ) and strategy } \\
\text { Vasopressor support (type and dose per kg per min) } \\
\text { and strategy (first line support, second line support) }\end{array}$ \\
\hline 4. ECMO type & $\begin{array}{l}\text { ECMO configuration } \\
\text { Method of cannulation }\end{array}$ & $\begin{array}{l}\text { Peripheral (except in post-cardiotomy setting) } \\
\text { Percutaneous femoral access (except in post- } \\
\text { cardiotomy setting) }\end{array}$ \\
\hline 5. ECMO equipment & $\begin{array}{l}\text { Pump and oxygenator model } \\
\text { Canula model and size } \\
\text { Placement confirmation } \\
\text { (if peripheral) }\end{array}$ & Use Maastricht treaty nomenclature [9] \\
\hline 6. ECMO settings & $\begin{array}{l}\text { Flow targets } \\
\text { Gas exchange targets } \\
\text { Anticoagulation treatment } \\
\text { and target }\end{array}$ & $\begin{array}{l}60-80 \mathrm{~mL} / \mathrm{kg} / \mathrm{min} \\
\mathrm{FmO} 2 \mathrm{minimal} \text {, sweep gas flow to maintain } \\
\text { stable } \mathrm{pH}\end{array}$ \\
\hline
\end{tabular}

ECMO extracorporeal membrane oxygenation; FmO2 membrane fraction of oxygen; LVEF left ventricular ejection fraction; LVOT left ventricular outflow tract; MAP mean arterial pressure; SVO2 venous saturation of oxygen; VTI velocity-time index 


\section{Conclusion}

In this systematic review, an overview of contemporary animal models of heart failure supported by veno-arterial extracorporeal membrane oxygenation was given. There is a large heterogeneity in methodology for heart failure induction, as well as ECMO management reporting. Future studies should aim at minimizing those reporting failuresmost likely through the use of a minimum dataset-in order to standardize these preclinical experiments and help better translation to clinical studies.

\section{Supplementary information}

Supplementary information accompanies this paper at https://doi.org/10.1186/s40635-020-00303-5.

Additional file 1.

\section{Acknowledgements}

The authors would like to acknowledge Miss Marie Lyager for her English review and proofreading, and Dr. Emmanuel Pardo, MD for the illustration.

\section{Authors' contributions}

SH, IR, SR, and JFF conceived the review. SR wrote the first draft of the manuscript. SH and SR edited the draft and rewrote individual sections. All authors participated in the final edit and in review of the manuscript. All authors read and approved the final manuscript.

\section{Funding}

Publication of this article was funded by the Australian National Health and Medical Research Council (NHRMC) Centre for Research Excellence in Advanced Cardio-respiratory Therapies Improving OrgaN Support (CREACTIONS). The contents are solely the responsibility of the authors and do not reflect the views of the NHMRC.

$\mathrm{SH}$ received a scholarship from the University of Queensland and The Prince Charles Foundation (Australia) for his PhD.

Availability of data and materials

All data and materials are available per request.

\section{Ethics approval and consent to participate}

Non-applicable

\section{Consent for publication}

All authors consent for publication.

\section{Competing interests}

The authors declare that they have no conflicts of interests.

\section{Author details}

${ }^{1}$ Critical Care Research Group, The Prince Charles Hospital, University of Queensland, Chermside, Brisbane, Australia. ${ }^{2}$ Second Department of Intensive Care, North Estonia Medical Centre, Talinn, Estonia. ${ }^{3}$ Sorbonne Université, INSERM, UMRS-1 166, ICAN Institute of Cardiometabolism and Nutrition, Medical ICU, Pitié-Salpêtrière University Hospital, 47, bd de l'Hôpital, 75651 Paris Cedex 13, France. ${ }^{4}$ Department of Internal Medicine II, Cardiology and Pneumology, University Medical Center Regensburg, Regensburg, Germany. ${ }^{5}$ Department of Perfusion, University Hospital Gasthuisberg, Louven, Belgium. ${ }^{6}$ ECMO Centre Karolinska, Karolinska University Hospital, Stockholm, Sweden. ${ }^{7}$ Department of Physiology and Pharmacology, Karolinska Institutet, Stockholm, Sweden. ${ }^{8}$ Wellcome-Wolfson Centre for Experimental Medicine, Queen's University Belfast, Belfast, UK.

Received: 8 October 2019 Accepted: 11 May 2020

Published online: 25 May 2020

\section{References}

1. Keebler ME, Haddad EV, Choi CW, McGrane S, Zalawadiya S, Schlendorf KH, Brinkley DM, Danter MR, Wigger M, Menachem JN, Shah A, Lindenfeld J (2018) Venoarterial extracorporeal membrane oxygenation in cardiogenic shock. JACC Heart Fail 6:503-516

2. Corsi F, Lebreton G, Bréchot N, Hekimian G, Nieszkowska A, Trouillet J-L, Luyt C-E, Leprince P, Chastre J, Combes A, Schmidt M (2017) Life-threatening massive pulmonary embolism rescued by venoarterial-extracorporeal membrane oxygenation. Crit Care 21:76

3. Brechot N, Luyt CE, Schmidt M, Leprince P, Trouillet JL, Leger P, Pavie A, Chastre J, Combes A (2013) Venoarterial extracorporeal membrane oxygenation support for refractory cardiovascular dysfunction during severe bacterial septic shock. Crit Care Med 41:1616-1626

4. Thiagarajan RR, Barbaro RP, Rycus PT, McMullan DM, Conrad SA, Fortenberry JD, Paden ML, Centers Em (2017) Extracorporeal Life Support Organization Registry International Report 2016. ASAIO J 63:60-67 
5. Huang CC, Hsu JC, Wu YW, Ke SR, Huang JH, Chiu KM, Liao PC (2018) Implementation of extracorporeal membrane oxygenation before primary percutaneous coronary intervention may improve the survival of patients with ST-segment elevation myocardial infarction and refractory cardiogenic shock. Int J Cardiol 269:45-50

6. Abrams D, Garan AR, Abdelbary A, Bacchetta M, Bartlett RH, Beck J, Belohlavek J, Chen YS, Fan E, Ferguson ND, Fowles JA, Fraser J, Gong M, Hassan IF, Hodgson C, Hou X, Hryniewicz K, Ichiba S, Jakobleff WA, Lorusso R, MacLaren G, McGuinness S, Mueller T, Park PK, Peek G, Pellegrino V, Price S, Rosenzweig EB, Sakamoto T, Salazar L, Schmidt M, Slutsky AS, Spaulding C, Takayama H, Takeda K, Vuylsteke A, Combes A, Brodie D, International EN, The Extracorporeal Life Support O (2018) Position paper for the organization of ECMO programs for cardiac failure in adults. Intensive Care Med 44:717-729

7. Liberati A, Altman DG, Tetzlaff J, Mulrow C, Gotzsche PC, loannidis JP, Clarke M, Devereaux PJ, Kleijnen J, Moher D (2009) The PRISMA statement for reporting systematic reviews and meta-analyses of studies that evaluate healthcare interventions: explanation and elaboration. BMJ 339:b2700

8. Leenaars $M$, Hooijmans $C R$, van Veggel $N$, ter Riet $G$, Leeflang $M$, Hooft $L$, van der Wilt GJ, Tillema A, Ritskes-Hoitinga M (2012) A step-by-step guide to systematically identify all relevant animal studies. Lab Anim 46:24-31

9. Conrad SA, Broman LM, Taccone FS, Lorusso R, Malfertheiner MV, Pappalardo F, Di Nardo M, Belliato M, Grazioli L, Barbaro RP, McMullan DM, Pellegrino V, Brodie D, Bembea MM, Fan E, Mendonca M, Diaz R, Bartlett RH (2018) The Extracorporeal Life Support Organization Maastricht treaty for nomenclature in extracorporeal life support. A position paper of the Extracorporeal Life Support Organization. Am J Respir Crit Care Med 198:447-451

10. de Vries RB, Hooijmans CR, Tillema A, Leenaars M, Ritskes-Hoitinga M (2011) A search filter for increasing the retrieval of animal studies in Embase. Lab Anim 45:268-270

11. Hooijmans CR, Tillema A, Leenaars M, Ritskes-Hoitinga M (2010) Enhancing search efficiency by means of a search filter for finding all studies on animal experimentation in PubMed. Lab Anim 44:170-175

12. Kilkenny C, Browne W, Cuthill IC, Emerson M, Altman DG, Group NCRRGW (2010) Animal research: reporting in vivo experiments: the ARRIVE guidelines. Br J Pharmacol 160:1577-1579

13. McMurray JJ, Adamopoulos S, Anker SD, Auricchio A, Bohm M, Dickstein K, Falk V, Filippatos G, Fonseca C, GomezSanchez MA, Jaarsma T, Kober L, Lip GY, Maggioni AP, Parkhomenko A, Pieske BM, Popescu BA, Ronnevik PK, Rutten FH, Schwitter J, Seferovic P, Stepinska J, Trindade PT, Voors AA, Zannad F, Zeiher A, Guidelines ESCCFP (2012) ESC Guidelines for the diagnosis and treatment of acute and chronic heart failure 2012: the task force for the diagnosis and treatment of acute and chronic heart failure 2012 of the European Society of Cardiology. Developed in collaboration with the Heart Failure Association (HFA) of the ESC. Eur Heart J 33:1787-1847

14. Ponikowski P, Voors AA, Anker SD, Bueno H, Cleland JGF, Coats AJS, Falk V, Gonzalez-Juanatey JR, Harjola VP, Jankowska EA, Jessup M, Linde C, Nihoyannopoulos P, Parissis JT, Pieske B, Riley JP, Rosano GMC, Ruilope LM, Ruschitzka F, Rutten FH, van der Meer P, Group ESCSD (2016) 2016 ESC Guidelines for the diagnosis and treatment of acute and chronic heart failure: the task force for the diagnosis and treatment of acute and chronic heart failure of the European Society of Cardiology (ESC) developed with the special contribution of the Heart Failure Association (HFA) of the ESC. Eur Heart J 37:2129-2200

15. Thiele H, Ohman EM, Desch S, Eitel I, de Waha S (2015) Management of cardiogenic shock. Eur Heart J 36:1223-1230

16. Prondzinsky R, Lemm H, Swyter M, Wegener N, Unverzagt S, Carter JM, Russ M, Schlitt A, Buerke U, Christoph A, Schmidt H, Winkler M, Thiery J, Werdan K, Buerke M (2010) Intra-aortic balloon counterpulsation in patients with acute myocardial infarction complicated by cardiogenic shock: the prospective, randomized IABP SHOCK Trial for attenuation of multiorgan dysfunction syndrome. Crit Care Med 38:152-160

17. Thiele H, Zeymer U, Neumann FJ, Ferenc M, Olbrich HG, Hausleiter J, de Waha A, Richardt G, Hennersdorf M, Empen K, Fuernau G, Desch S, Eitel I, Hambrecht R, Lauer B, Bohm M, Ebelt H, Schneider S, Werdan K, Schuler G, Intraaortic Balloon Pump in cardiogenic shock IIti (2013) Intra-aortic balloon counterpulsation in acute myocardial infarction complicated by cardiogenic shock (IABP-SHOCK II): final 12 month results of a randomised, open-label trial. Lancet 382 $1638-1645$

18. Sauren LD, Reesink KD, Selder JL, Beghi C, van der Veen FH, Maessen JG (2007) The acute effect of intra-aortic balloon counterpulsation during extracorporeal life support: an experimental study. Artif Organs 31:31-38

19. Bartoli CR, Koenig SC, Ionan C, Gillars KJ, Mitchell ME, Austin EH 3rd, Gray LA, Pantalos GM (2013) Extracorporeal membrane oxygenation versus counterpulsatile, pulsatile, and continuous left ventricular unloading for pediatric mechanical circulatory support. Pediatr Crit Care Med 14:e424-e437

20. Esposito ML, Shah N, Dow S, Kang S, Paruchuri V, Karas RH, Kapur NK (2016) Distinct effects of left or right atrial cannulation on left ventricular hemodynamics in a swine model of acute myocardial injury. ASAIO J 62:671-676

21. Kajimoto M, Ledee DR, Xu C, Kajimoto H, Isern NG, Portman MA (2014) Triiodothyronine activates lactate oxidation without impairing fatty acid oxidation and improves weaning from extracorporeal membrane oxygenation. Circ J 78: 2867-2875

22. Itoh H, Ichiba S, Ujike Y, Douguchi T, Obata H, Inamori S, Iwasaki T, Kasahara S, Sano S, Undar A (2016) Effect of the pulsatile extracorporeal membrane oxygenation on hemodynamic energy and systemic microcirculation in a piglet model of acute cardiac failure. Artif Organs 40:19-26

23. Yu JJ, Son HS, Lim CH, Lee JJ, Park YW, Her K, Won YS, Sun K, Choi JY (2008) Comparison of myocardial loading between asynchronous pulsatile and nonpulsatile percutaneous extracorporeal life support. ASAIO J 54:177-180

24. Janak D, Hala P, Mlcek M, Popkova M, Lacko S, Kudlicka J, Kittnar O (2017) Detection of microembolic signals in the common carotid artery using Doppler sonography in the porcine model of acute heart failure treated by veno-arterial extracorporeal membrane oxygenation. Physiol Res 66(Suppl. 4):S529-S536

25. Hala P, Mlcek M, Ostadal P, Janak D, Popkova M, Boucek T, Lacko S, Kudlicka J, Neuzil P (2016) Kittnar O, (2016) Regional tissue oximetry reflects changes in arterial flow in porcine chronic heart failure treated with venoarterial extracorporeal membrane oxygenation. Physiol Res 65(Suppl. 5):S621-S631

26. von Segesser LK, Kwang K, Tozzi P, Horisberger J, Dembitsky W (2008) A simple way to decompress the left ventricle during venoarterial bypass. Thorac Cardiovasc Surg 56:337-341

27. Brehm C, Schubert S, Carney E, Ghodsizad A, Koerner M, McCoach R, El-Banayosy A (2015) Left anterior descending coronary artery blood flow and left ventricular unloading during extracorporeal membrane oxygenation support in a swine model of acute cardiogenic shock. Artif Organs 39:171-176 
28. Naito N, Nishimura T, lizuka K, Fujii Y, Takewa Y, Umeki A, Ando M, Ono M, Tatsumi E (2017) Novel rotational speed modulation system used with venoarterial extracorporeal membrane oxygenation. Ann Thorac Surg 104:1488-1495

29. Ostadal P, Mlcek M, Gorhan H, Simundic I, Strunina S, Hrachovina M, Kruger A, Vondrakova D, Janotka M, Hala P, Mates M, Ostadal M, Leiter JC, Kittnar O, Neuzil P (2018) Electrocardiogram-synchronized pulsatile extracorporeal life support preserves left ventricular function and coronary flow in a porcine model of cardiogenic shock. PLoS One 13:e0196321

30. Ostadal P, Mlcek M, Kruger A, Hala P, Lacko S, Mates M, Vondrakova D, Svoboda T, Hrachovina M, Janotka M, Psotova H, Strunina S, Kittnar O, Neuzil P (2015) Increasing venoarterial extracorporeal membrane oxygenation flow negatively affects left ventricular performance in a porcine model of cardiogenic shock. J Transl Med 13:266

31. Simonsen C, Magnusdottir SO, Andreasen JJ, Rohde MC, Kjaergaard B (2018) ECMO improves survival following cardiogenic shock due to carbon monoxide poisoning - an experimental porcine model. Scand J Trauma Resusc Emerg Med 26:103

32. Zhu GJ, Sun LN, Li XH, Wang NF, Wu HH, Yuan CX, Li QQ, Xu P, Ren YQ, Mao BG (2015) Myocardial protection of early extracorporeal membrane oxygenation (ECMO) support for acute myocardial infarction with cardiogenic shock in pigs. Heart Vessel 30:669-674

33. Sakamoto K, Saku K, Kishi T, Kakino T, Tanaka A, Sakamoto T, Ide T, Sunagawa K (2015) Prediction of the impact of venoarterial extracorporeal membrane oxygenation on hemodynamics. Am J Physiol Heart Circ Physiol 308:H921-H930

34. Kawashima D, Gojo S, Nishimura T, Itoda Y, Kitahori K, Motomura N, Morota T, Murakami A, Takamoto S, Kyo S, Ono M (2011) Left ventricular mechanical support with Impella provides more ventricular unloading in heart failure than extracorporeal membrane oxygenation. ASAIO J 57:169-176

35. Moller-Helgestad OK, Hyldebrandt JA, Banke A, Rud CS, Udesen NLJ, Linde L, Okkels-Jensen L, Schmidt H, Ravn HB, Moller JE (2019) Impella CP or VA-ECMO in profound cardiogenic shock: left ventricular unloading and organ perfusion in a large animal model. Eurolntervention 14:e1585-e1592

36. Vanhuyse F, Ducrocq N, Louis H, Kattani NA, Laurent N, Joineau-Groubatch F, Falanga A, Maureira JP, Kimmoun A, Girerd N, Tran N, Levy B (2017) Moderate hypothermia improves cardiac and vascular function in a pig model of ischemic cardiogenic shock treated with veno-arterial ECMO. Shock 47:236-241

37. Kilkenny C, Parsons N, Kadyszewski E, Festing MF, Cuthill IC, Fry D, Hutton J, Altman DG (2009) Survey of the quality of experimental design, statistical analysis and reporting of research using animals. PLoS One 4:e7824

38. Avey MT, Moher D, Sullivan KJ, Fergusson D, Griffin G, Grimshaw JM, Hutton B, Lalu MM, Macleod M, Marshall J, Mei SH, Rudnicki M, Stewart DJ, Turgeon AF, Mclntyre L (2016) The devil is in the details: incomplete reporting in preclinical animal research. PLoS One 11:e0166733

39. Reardon S (2016) A mouse's house may ruin experiments. Nature 530:264

40. Golder S, Loke YK, Wright K, Norman G (2016) Reporting of adverse events in published and unpublished studies of health care interventions: a systematic review. PLoS Med 13:e1002127

41. Guglin M, Zucker MJ, Bazan VM, Bozkurt B, El Banayosy A, Estep JD, Gurley J, Nelson K, Malyala R, Panjrath GS, Zwischenberger JB, Pinney SP (2019) Venoarterial ECMO for adults: JACC scientific expert panel. J Am Coll Cardiol 73 : 698-716

42. Ranieri VM, Brodie D, Vincent $J$ (2017) Extracorporeal organ support: from technological tool to clinical strategy supporting severe organ failure. JAMA 318:1105-1106

43. Riehle C, Bauersachs J (2019) Small animal models of heart failure. Cardiovasc Res 115:1838-1849

44. Wollborn J, Siemering S, Steiger C, Buerkle H, Goebel U, Schick MA (2019) Phosphodiesterase-4 inhibition reduces ECLSinduced vascular permeability and improves microcirculation in a rodent model of extracorporeal resuscitation. Am J Physiol Heart Circ Physiol 316:H751-H761

45. Warenits AM, Sterz F, Schober A, Ettl F, Magnet IA, Hogler S, Teubenbacher U, Grassmann D, Wagner M, Janata A, Weihs W (2016) Reduction of serious adverse events demanding study exclusion in model development: extracorporeal life support resuscitation of ventricular fibrillation cardiac arrest in rats. Shock 46:704-712

46. Guo M, Yao D, Li L, Lu C, Li Y, Li J (2016) Intestinal conditioning after cardiac arrest: the use of normothermic extracorporeal membrane oxygenation in the non-heart-beating animal model. Artif Organs 40:738-745

47. Damian ACl, Stan FG, Dezdrobitu CC, Martonos CO, Papuc I, Crisan MC, Irimescu I, Tuns F (2015) Features of the subclavian arteries and their branching in the domestic pig. Vet Med LXI 1:25-30 available at: http:// veterinarymedicinejournal.usamv.ro/pdf/2015/issue_1/Art3.pdf

48. Byrom MJ, Bannon PG, White GH, Ng MK (2010) Animal models for the assessment of novel vascular conduits. J Vasc Surg 52:176-195

49. A K (2008) Animal models of atherosclerosis, restenosis, and endovascular aneurysm repair. Sourcebook of models for biomedical research: 369-384

50. Dixon JA, Spinale FG (2009) Large animal models of heart failure: a critical link in the translation of basic science to clinical practice. Circ Heart Fail 2:262-271

51. Thomaz PG, Assad RS, Abduch MC, Marques E, Aiello VD, Stolf NA (2009) Assessment of a new experimental model of isolated right ventricular failure. Artif Organs 33:258-265

52. Wan Z, Ristagno G, Sun S, Li Y, Weil MH, Tang W (2009) Preserved cerebral microcirculation during cardiogenic shock. Crit Care Med 37:2333-2337

53. Merino D, Gil A, Gomez J, Ruiz L, Llano M, Garcia R, Hurle MA, Nistal JF (2018) Experimental modelling of cardiac pressure overload hypertrophy: modified technique for precise, reproducible, safe and easy aortic arch bandingdebanding in mice. Sci Rep 8:3167

54. Spannbauer A, Traxler D, Zlabinger K, Gugerell A, Winkler J, Mester-Tonczar J, Lukovic D, Muller C, Riesenhuber M, Pavo N, Gyongyosi M (2019) Large animal models of heart failure with reduced ejection fraction (HFrEF). Front Cardiovasc Med 6:117

55. ELSO (2018) Guidelines for adult cardiac failure. https://www.elso.org/resources/guidelines.aspx

\section{Publisher's Note}

Springer Nature remains neutral with regard to jurisdictional claims in published maps and institutional affiliations. 